\title{
Seasonal dynamics of prey size mediate complementary functions of mussel beds and seagrass habitats for an avian predator
}

\author{
Eric M. Anderson ${ }^{1,2, *}$, James R. Lovvorn ${ }^{1,3}$ \\ ${ }^{1}$ Department of Zoology and Physiology, University of Wyoming, 1000 E. University Avenue, Laramie, Wyoming 82071, USA \\ ${ }^{2}$ Present address: Department of Renewable Resources, British Columbia Institute of Technology, 3700 Willingdon Avenue, \\ Burnaby, British Columbia V5G 3H2, Canada \\ ${ }^{3}$ Present address: Department of Zoology and Center for Ecology, Southern Illinois University, Carbondale, Illinois 62901, USA
}

\begin{abstract}
Foraging profitability can be strongly affected by the size structure of different prey, so that predator distributions are not a simple function of total prey biomass. For a bottom-feeding avian predator, the surf scoter Melanitta perspicillata, we assessed effects of prey size and other prey attributes on seasonal shifts in scoter use of 2 major foraging habitats in Puget Sound, Washington, USA. During early winter, many thousands of scoters fed at an unvegetated site where profitable prey appeared limited to mussels Mytilus trossulus of smaller sizes (2 to $30 \mathrm{~mm}$ ) despite their much lower biomass relative to larger mussels and several other prey types. Accordingly, scoter numbers decreased at that site as small mussels declined over winter. During pre-migratory fattening in spring and feather molt in summer, $>8000$ surf scoters aggregated at a seagrass site where they fed mainly on epifaunal crustaceans (50 to $73 \%$ ) and gastropods (12 to $27 \%$ ). Body sizes of most crustacean prey had increased substantially since winter. Thus, prey size had opposite effects on the profitability of unvegetated habitats that provide mainly mussels (smaller items likely reduce shell processing costs) versus seagrass crustaceans (larger items are likely more visible and yield greater energy per prey item, although relative mobility of prey can alter their value). Total prey biomass, and prey distributions relative to water and sediment depths, appeared less important than prey size to shifts in scoter diets and numbers. Our synthesis of past studies indicates that biomass and production of mussel beds are typically an order of magnitude greater than for entire assemblages of seagrass macroinvertebrates. However, because of seasonal shifts in prey size structure, seagrass sites can be an important complement to mussel beds when the narrow size fraction of mussels that are profitable to scoters declines.
\end{abstract}

KEY WORDS: Epifauna $\cdot$ Foraging profitability $\cdot$ Marine habitat $\cdot$ Melanitta perspicillata $\cdot$ Prey biomass $\cdot$ Size selection of prey $\cdot$ Surf scoter Resale or republication not permitted without written consent of the publisher

\section{INTRODUCTION}

Mapping prey abundance can help delineate potentially suitable foraging sites (Durell et al. 2005), yet these sites often support fewer predators than expected based on total prey abundance (Nilsson 1972, Goss-Custard et al. 2002). Such discrepancies can occur because appreciable fractions of prey are not profitable to predators (Zwarts \& Wan- ink 1993, Richman \& Lovvorn 2009) and because relative foraging values change seasonally and annually among sites that differ in dominant prey types. These effects can cause predators to shift to other habitats before seemingly available foods are exhausted (Nolet et al. 2006). Thus, identifying attributes of prey that determine their relative value is essential to protecting the range of habitat types that a predator needs. 
Predators usually select prey based on their relative profitability (energy gain minus cost), which is affected by a range of factors before and after prey capture. Before prey capture, profitability depends largely on the density and dispersion of prey, as well as the ability of prey to evade predators by being cryptic or highly mobile (Christensen 1996, Lovvorn \& Gillingham 1996, Sih \& Christensen 2001). Also important before prey capture is the ability of predators to detect and access prey, which is often related to the structural complexity of the feeding habitat (Crowder \& Cooper 1982, Lundvall et al. 1999). After prey capture, profitability depends on the nutrient and energy content of prey and on factors that affect processing rate such as relative composition of indigestible material (e.g. shell, bone; van Gils et al. 2003). Processing rates are also influenced by predator physiology and morphology (e.g. assimilation efficiency, sizes of mouth and gut; Hughes \& Dunkin 1984, Richman \& Lovvorn 2003).

Factors that determine foraging profitability often scale with the relative sizes of predators and their prey (Christensen 1996, Lundvall et al. 1999, Costa 2009). Thus, for a given predator, shifts in the size structure of available prey can explain changes in foraging profitability. Some prey attributes can result in predators selecting prey that appear suboptimal based on their size alone (Sih \& Christensen 2001). For instance, increased shell content of prey typically results in predators choosing smaller prey than expected, while the size of mobile prey selected can depend on encounter and capture rates as affected by prey mobility and visibility (Christensen 1996, Hamilton et al. 1999, Sih \& Christensen 2001). Predicting relative foraging values among habitats requires knowing how prey size interacts with a range of other prey attributes (Goudie \& Ankney 1986).

Predators that are highly mobile may rely on a sequence of feeding habitats as different prey communities undergo seasonal changes in size structure. Mussel and seagrass beds are heavily used feeding sites for many predators (Hamilton 2000, Heck \& Orth 2006), yet these sites are characterized by distinct suites of feeding conditions that likely affect their relative value. Mussels rely mainly on shells to counter traits that can make them highly profitable prey, such as their high visibility, dense aggregations, and immobility. Conversely, many seagrass invertebrates lack shells, instead relying on low visibility or high mobility to reduce predation (Heck \& Orth 2006). In addition to many seagrass invertebrates lacking shells, macroinvertebrate abundance is typically much greater in seagrass than in unvegetated habi- tats (Heck et al. 1995). However, an exception to this latter pattern exists for mussel beds, which have biomass and production that are an order of magnitude greater than for entire communities of seagrass macroinvertebrates (Fig. 1). While levels of biomass and production are clearly important, the amount of profitable prey in each habitat may depend more on the interaction of prey size structure with factors such as shell content, visibility, and mobility.

For mussel-dominated and seagrass habitats, we assessed the relative importance of several prey attributes to the foraging distributions of an avian predator. We focused on surf scoters Melanitta per-

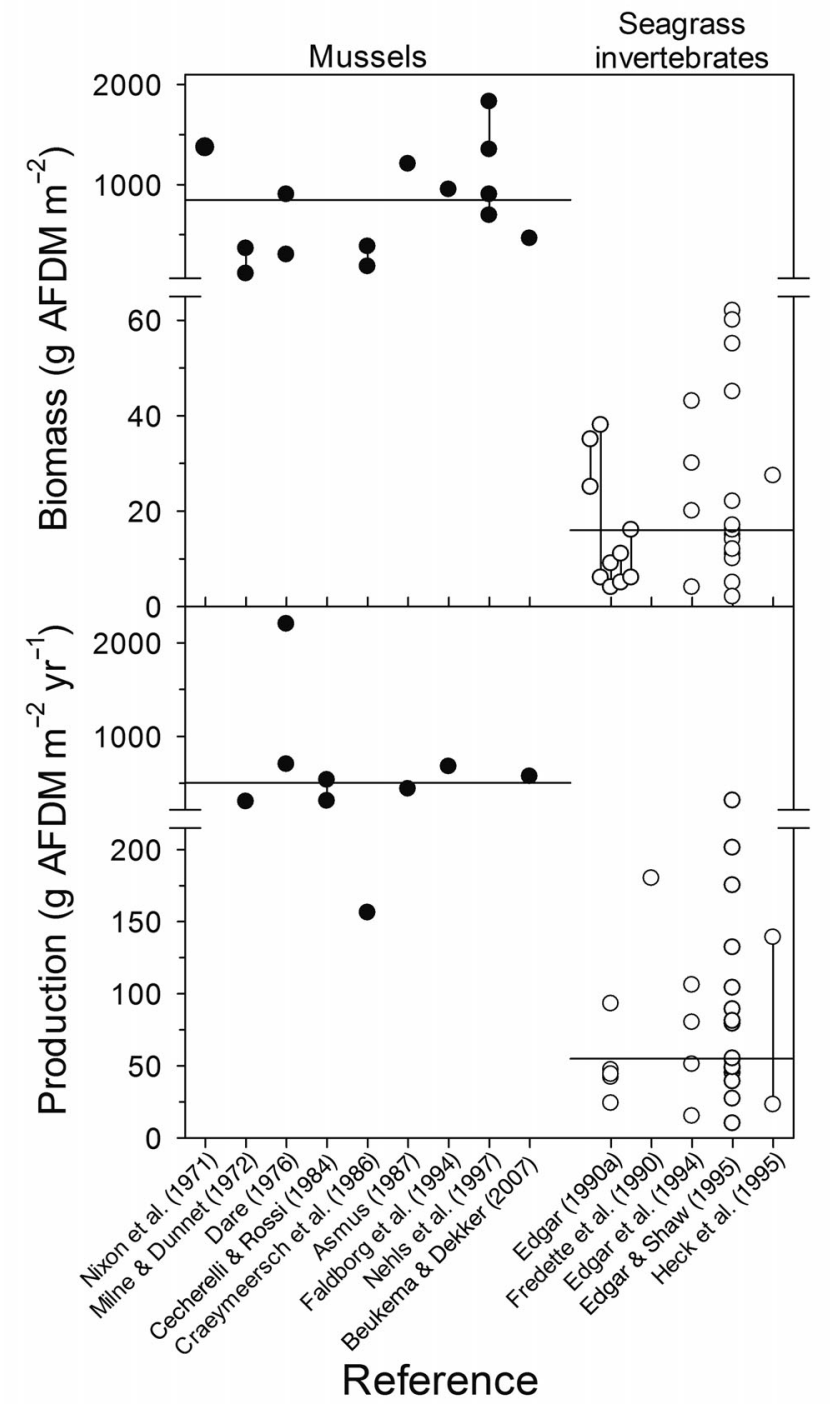

Fig. 1. Estimates from past studies in temperate regions (4 to $24^{\circ} \mathrm{C}$ ) of biomass and production for beds of mussels (Mytilus spp.) and seagrass macrofauna (O: infauna + epifauna). Several studies provided estimates from multiple sites; both biomass and production were not available for all sites. Vertical lines connect seasonal estimates for single sites; horizontal lines are median values 
spicillata, a declining yet widely distributed sea duck that feeds in marine habitats for most of the year. Although sea ducks consume a range of benthic macroinvertebrates, bivalve prey are often of high value to many sea duck species (Stott \& Olson 1973, Goudie \& Ankney 1986, Anderson et al. 2008). Accordingly, the importance of marine foraging sites to sea ducks is commonly assessed in terms of the availability of bivalves in unvegetated habitats (Nilsson 1980, Nehls \& Ketzenberg 2002, Sukhotin et al. 2008). However, at heavily used foraging sites, bivalves may decline over periods ranging from a single foraging season to many years (Beukema \& Dekker 2007, Kirk et al. 2007). Such declines elevate the importance of alternative feeding habitats and of different prey characteristics that affect foraging profitability. In this study, we assess the importance of the seasonal size dynamics of prey to a shift by foraging scoters from mussel beds in early winter to seagrass meadows during pre-migratory fattening in spring and feather molt in late summer.

\section{MATERIALS AND METHODS}

\section{Study sites}

We conducted research in 2 bays in northern Puget Sound, Washington, USA, that were heavily used by surf scoters Melanitta perspicillata during at least part of the annual cycle. Penn Cove $\left(48.2^{\circ} \mathrm{N}, 122.7^{\circ} \mathrm{W}\right)$ is largely unvegetated and has a narrow intertidal zone within which mussels Mytilus trossulus are common. Padilla Bay $\left(48.5^{\circ} \mathrm{N}, 122.5^{\circ} \mathrm{W}\right)$, which is mainly intertidal, contains one of the largest contiguous seagrass beds on the Pacific Coast of North America (3208 ha). Seagrasses in Padilla Bay were mainly Zostera marina ( $>90 \%$ of areal extent), with minor components of $Z$. aponica and Ruppia maritima (Bulthuis 1995). Maximum depths at mean lower low water (MLLW) were $\sim 25 \mathrm{~m}$ in Penn Cove and $\sim 2 \mathrm{~m}$ in Padilla Bay. We observed scoters diving throughout each bay.

\section{Study design}

We related seasonal changes in surf scoter numbers in each bay to several prey attributes that can affect profitability, including seasonal prey biomass (in terms of ash-free dry mass [AFDM]), prey size, water depth, and burial depth in sediments. We sampled these prey attributes at each site during 3 seasonal periods (November to January, March to May, and August) over 2 yr. To corroborate effects of prey attributes on changes in surf scoter numbers, we also assessed scoter diet at each site during the seasonal periods when their abundance was greatest. Numbers of surf scoters in Penn Cove declined in midwinter (see 'Results'), a period in which movement among seasonal habitats does not typically occur. To assess reasons for these overwinter departures, we used an energetics model to relate estimates of surf scoter nutritional requirements to the availability of foods that were heavily used in Penn Cove.

We predicted that seasonal changes in total prey biomass at each site would explain changes in surf scoter numbers and that the importance of total biomass would be mediated by prey size (see below) as well as by prey distributions relative to water depth and burial depth in sediments. Increased water depth and sediment burial depth of prey reduce foraging profitability for bottom-feeding ducks (Lovvorn 1994, Richman \& Lovvorn 2004). We expected valuable prey to include mussels in Penn Cove during early winter and seagrass-associated invertebrates in Padilla Bay between spring and autumn. Mussels typically recruit in early summer and within 3 to 5 mo attain shell lengths of 5 to $15 \mathrm{~mm}$, which is within the range of bivalve sizes sea ducks often prefer (Fig. 2; Hamilton et al. 1999, Beukema \& Dekker 2007). For seagrass invertebrates, the seasonal timing of maximum abundance varies among sites and taxa, although peaks often occur between late spring and autumn (Edgar 1990b, McMillan et al. 1995, Nakaoka et al. 2001).

Assuming other factors remained constant, we predicted that the effect of increased prey size on the profitability to surf scoters would vary by habitat and prey type. For shelled prey including mainly bivalves, diving ducks prefer relatively small individuals, probably to reduce the costs of handling and processing shells (diving ducks consume whole bivalves; Richman \& Lovvorn 2004). Thus, we predicted that seasonal changes in biomass within progressively larger bivalve size classes would have a decreasing effect on surf scoter foraging profitability and numbers at each site. Mussels may be a singularly important food for surf scoters in Penn Cove, but Padilla Bay likely supports a greater range of potential prey including crustaceans that are particularly abundant in many seagrass beds (Edgar \& Shaw 1995, Nakaoka et al. 2001). Crustaceans lack hard calcareous shells and vary in their relative mobility. Thus, increased size of crustacean prey likely entails a tradeoff for surf scoters: while larger prey will be more visible and provide more energy per prey capture, swimming velocity and thus ability to evade preda- 


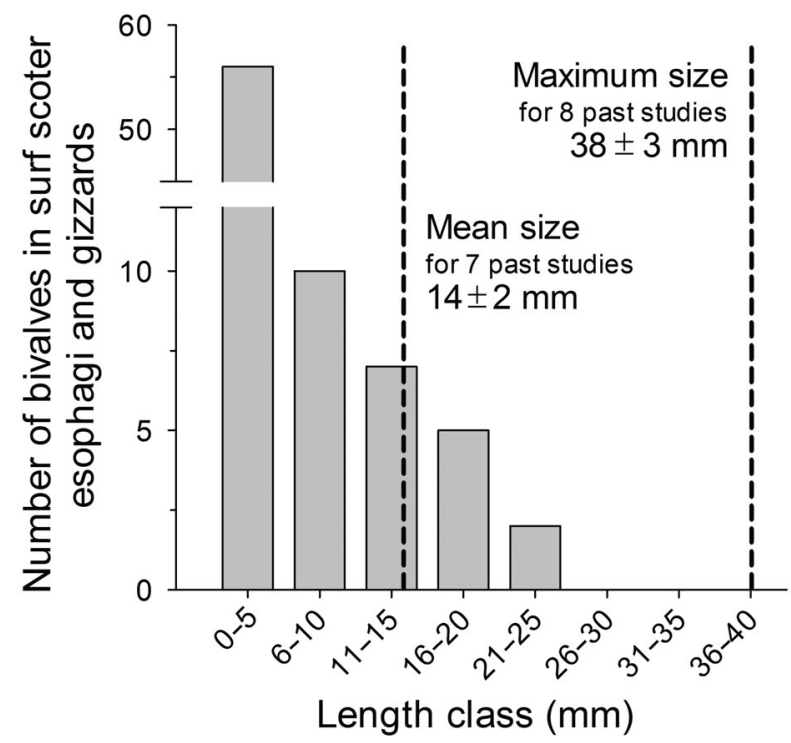

Fig. 2. Melanitta perspicillata. Shell lengths of whole bivalves consumed by 60 surf scoters including those collected for this and related studies from 2005 to 2006 in Puget Sound, Washington (results exclude 3 individual bivalves of atypical shape that were rare in our study sites). Vertical dashed lines indicate averages across past studies of the mean and maximum lengths of bivalves consumed by surf scoters. Results are from Anderson et al. (2008)

tors can also increase with size for many crustacean prey. To assess the effect of this tradeoff on surf scoter foraging profitability, we considered the seasonal size dynamics for 2 taxa of crustaceans that are particularly common in Padilla Bay (Ray 1997), but that show different patterns of mobility relative to size. The isopod Idotea resecata shows no change in swimming velocity with size $\left(0.2 \mathrm{~m} \mathrm{~s}^{-1}\right.$; Alexander \& Chen 1990), while velocity is greater and increases markedly with size in caridean shrimp $\left(0.5 \mathrm{~m} \mathrm{~s}^{-1}\right.$ versus $>1.0 \mathrm{~m} \mathrm{~s}^{-1}$ at 10 and $30 \mathrm{~mm}$ body lengths, respectively; Arnott et al. 1998). Thus, we predicted that the profitability to surf scoters would increase with prey size for $I$. resecata more so than for caridean shrimp. We assessed seasonal changes in the size of these crustaceans in terms of their body length and AFDM per individual and assessed profitability in terms of their relative representation in surf scoter diets.

\section{Field studies}

Surf scoter counts

We counted surf scoters in each bay from shore with a $20 \times$ to $60 \times$ spotting scope. We conducted counts approximately biweekly in Penn Cove from
November to May of 2003 to 2005 and in Padilla Bay from November to September of 2004 to 2005. To assess scoter trends throughout the annual cycle from 2003 to 2006, we supplemented biweekly counts with irregular counts in each bay from December to September of 2005 to 2006, informal observations, and results of shoreline counts in Padilla Bay from 2003 to 2004 conducted by others (J. L. Bower, Western Washington University, unpubl. data).

\section{Surf scoter diets}

Surf scoters were killed with a shotgun from small boats and collected. To avoid partitioning our limited sample size among multiple sex and age classes, we collected only after-hatch-year males; we did not observe sex- or age-related segregation in foraging areas within each site (E. M. Anderson unpubl. data). We verified age class and sex and conducted all diet analyses as in Anderson et al. (2008). So that diet estimates would correspond approximately to the peak periods during which each site was used (see 'Results'), we collected surf scoters in Penn Cove on 11 and 12 December $2005(\mathrm{n}=9)$ and in Padilla Bay on 29 August $2005(\mathrm{n}=9)$ and from 12 to 27 March 2006 $(\mathrm{n}=10)$. In Penn Cove, mid-winter departures of surf scoters occurred earlier in 2005 to 2006 than in the previous 2 winters, so we also assessed diet for a sample of hunter-killed surf scoters collected from November to December 2003 ( $\mathrm{n}=7$ ). Hunter-killed birds were shot over decoys and stored whole at $-20^{\circ} \mathrm{C}$ within $10 \mathrm{~h}$ of collection. All esophagi were empty for hunter-killed birds from Penn Cove and for those we collected in Padilla Bay during August 2005. Thus, we used gizzard contents to assess diet for these 2 samples of surf scoters. Both the sampling methods used for hunter-killed birds and the use of gizzard instead of esophagus contents mean that associated diet results likely underestimate the importance of soft-bodied prey (mainly crustaceans and polychaetes; Anderson et al. 2008).

Infaunal prey surveys

We sampled infaunal invertebrates at each site during 6 periods: 23 November to 31 December 2003, 3 to 18 May 2004, 16 to 29 August 2004, 10 December 2004 to 16 January 2005, 27 March to 26 May 2005, and 9 to 20 August 2005. Within each site, we established 2 transects that were perpendicular to the shoreline and intersected locations where we com- 
monly observed feeding by scoters. Transects in Padilla Bay extended to a water depth of $2 \mathrm{~m}$ at MLLW. Because the width of the intertidal zone in Penn Cove was relatively narrow and a large proportion of feeding by scoters occurred at subtidal elevations, we extended transects in that site to a water depth of $6 \mathrm{~m}$ at MLLW. Transect lengths were $0.12 \mathrm{~km}$ in Penn Cove and $4 \mathrm{~km}$ in Padilla Bay. We collected infaunal samples using a corer with $10 \mathrm{~cm}$ diameter $\times 10 \mathrm{~cm}$ depth, preserving separately 0 to $5 \mathrm{~cm}$ and 5 to $10 \mathrm{~cm}$ depth segments (see below). Although the maximum depth in sediments to which surf scoters will excavate infaunal prey is not known, we limited our core depth to $10 \mathrm{~cm}$ because the profitability of most prey at greater sediment depths is likely very low (Richman \& Lovvorn 2004). Along each transect, we collected 3 replicate core samples at each of 12 stations in Penn Cove and 10 stations in Padilla Bay, where stations were spaced equidistantly. In Penn Cove, 4 stations on each of the 2 transects occurred at subtidal elevations where cores were collected with the assistance of divers using SCUBA; all other cores were collected from the beach at low tide or from a small boat. A GPS was used to guide repeated sampling of the same stations across seasons for infaunal and epifaunal surveys.

\section{Epifaunal prey surveys}

In Penn Cove, we sampled mussels at intertidal elevations during the 6 periods described above; we did not observe mussels at subtidal elevations. Beginning at the intersection of each of the 2 benthic transects with shoreline, we established a $200 \mathrm{~m}$ baseline parallel to the shore along the highest elevation at which mussels were observed. Transects of $20 \mathrm{~m}$ length were then positioned every $10 \mathrm{~m}$ along the baseline, running from the baseline toward the water. We collected all mussels within a $20 \times 20 \mathrm{~cm}$ quadrat placed randomly along each of two $10 \mathrm{~m}$ segments of each transect ( $\mathrm{n}=80$ quadrats during each of the first 3 sampling periods), or along each of four $5 \mathrm{~m}$ segments of each transect ( $\mathrm{n}=160$ quadrats during each of the final 3 sampling periods).

We sampled epifaunal invertebrates other than mussels using an epibenthic sled with an opening $50 \mathrm{~cm}$ wide $\times 15 \mathrm{~cm}$ high and a mesh size smaller than the $2 \mathrm{~mm}$ sieve used to sort samples (see below). Sampling was conducted during 5 periods, including all periods described above for infaunal sampling, except during August 2004 when sampling equipment was not available. Beginning at each of the 2 benthic tran- sects, the epibenthic sled was pulled behind a small boat for three 2 min tows along each of 3 depth contours ( $\mathrm{n}=18$ tows per sampling period in each site). For the final 3 sampling periods, we conducted tows from 1 additional transect in Padilla Bay ( $\mathrm{n}=27$ tows per sampling period) to achieve better representation of surf scoter foraging habitats in this relatively large bay. A GPS was used to maintain a constant bottom speed of about $3 \mathrm{~km} \mathrm{~h}^{-1}$ during tows and to measure the length of each tow. The mean length of all epibenthic tows was $80 \mathrm{~m}(\mathrm{SE}=1 \mathrm{~m})$. Seagrass stands in Padilla Bay were often of greater height than the sled opening, and epibenthic sleds do not capture all animals per unit area that inhabit stands of vegetation. Thus, we report epifaunal biomass by volume through which the sled opening was towed rather than by area, and these results are not comparable to values obtained with other sampling devices.

\section{Laboratory analyses}

In surf scoter esophagi and gizzards, whole prey were rarely $<2 \mathrm{~mm}$ in length, but soft-bodied prey (crustaceans, polychaetes) were often highly fragmented. Thus, esophagus and gizzard contents were rinsed over a $0.5 \mathrm{~mm}$ sieve to avoid missing smaller fragments, while infaunal and epifaunal prey samples were rinsed over a $2 \mathrm{~mm}$ sieve. Invertebrates from all samples were stored at $-20^{\circ} \mathrm{C}$ until processed and were later sorted to the lowest possible taxon with a dissecting microscope $\left(10 x_{i}\right.$ Kozloff 1996). For all esophagus and gizzard contents and for representative individuals of prey samples (see below), we measured AFDM $( \pm 0.001 \mathrm{~g})$ by drying invertebrates to constant mass at $60^{\circ} \mathrm{C}$ and then measuring loss of mass on combustion at $500^{\circ} \mathrm{C}$ for $8 \mathrm{~h}$. For prey samples, we converted numerical densities of invertebrates to AFDM using site- and season-specific conversion factors that we developed for each taxon, including size-specific conversions for all bivalves and crabs (E. M. Anderson unpubl. data). Because many invertebrates were small, these conversion factors were often based on AFDM estimates of multiple pooled samples of individuals.

Consumption of echinoderms by surf scoters at our sites was limited to Ophiuroidea (brittle stars). Thus, we excluded from prey samples other taxa of echinoderms, which included mainly large Asteroidea (sea stars) and Echinoidea (urchins). Polychaetes, ophiuroids, and small bivalves were distributed widely among depths in the sediments, yet often occurred at the sediment surface. These taxa were included only 
in infaunal samples, because small invertebrates located at the sediment surface were not effectively sampled by the epibenthic sled. Thus, for analyses of infaunal core samples, we included bivalves (except mussels), crustaceans (amphipods and Pinnotheridae crabs), polychaetes, and ophiuroids (no gastropods occurred in infaunal samples). For analyses of epibenthic sled samples, we included all gastropods and crustaceans.

For prey samples and contents of surf scoter esophagi and gizzards, we measured $( \pm 1 \mathrm{~mm})$ shell length along the longest axis for all bivalves, maximum carapace width for all intact crabs, and body length (not including antennae of crustaceans) for representative seasonal samples of epifauna in Padilla and Birch Bays. We evaluated the availability of bivalves at each site within the size classes 2 to 20 , 21 to 30,31 to 40 , and 41 to $60 \mathrm{~mm}$. Bivalves of length $>60 \mathrm{~mm}$ appeared inaccessible to surf scoters and were thus excluded from analyses. Crabs were not abundant enough in our samples to evaluate their availability by size classes, and we arbitrarily excluded crabs of carapace width $>40 \mathrm{~mm}$, because the size range of crabs eaten by surf scoters was not available. Compared to bivalves, we selected a smaller size threshold for crabs because their carapace width does not include legs.

\section{Data analyses and computations}

We conducted statistical analyses using JMP 8.0.2 (SAS Institute). For major taxonomic categories of infauna and epifauna at each site, we used nested ANOVA to assess seasonal changes in total prey biomass and in distributions of prey relative to sediment burial depth (infauna only) and water depth. In addition to sampling season (November to January, March to May, August), each model included terms for year, season $\times$ year, and (for bivalves only) size class and season $\times$ size class. For analyses of core and epibenthic sled data, triplicate samples were nested within station and transect. For analyses of mussels in Penn Cove, quadrat samples were nested within a $200 \mathrm{~m}$ baseline.

For analyses of seasonal changes in infaunal biomass, we considered prey within 0 to $10 \mathrm{~cm}$ sediment depths. To assess whether changes in prey distribution relative to sediment burial depth explained changes in surf scoter numbers at each site, we evaluated seasonal changes in infaunal biomass within 0 to $5 \mathrm{~cm}$ sediment depths. For each site, prey burial depth was considered important where changes in biomass within 0 to $5 \mathrm{~cm}$, but not within 0 to $10 \mathrm{~cm}$, depths were consistent with changes in scoter numbers. Similarly, for prey distributions relative to water depth, we considered seasonal changes in the biomass of infauna and epifauna for the sampling stations closest to the shoreline along each transect. These included 5 triplicate core stations ( 6 in Penn Cove where each transect had 12 stns) and 2 triplicate epibenthic sled stations. For each site, water depth of prey was considered important to scoters if changes in biomass at shallower stations, but not all stations, corresponded to changes in scoter numbers. We did not assess the effects of changes in water depth for mussels, which were limited to relatively shallow water.

We related the availability of heavily used foods in Penn Cove to the energetic requirements (ER) of surf scoters estimated as:

$$
\mathrm{ER}=[\mathrm{FMR} /(\mathrm{ED} \times \mathrm{AE})] \times \mathrm{SSUD}
$$

where FMR (field metabolic rate) was estimated from body mass $M_{\mathrm{b}}$ (in $\mathrm{g}$ ) by:

$$
\log \text { FMR }\left(\mathrm{kJ} \mathrm{d}^{-1}\right)=0.904+\left(0.704 \times \log M_{\mathrm{b}}\right)
$$

as reported for seabirds (Nagy 1987). Surf scoter body mass (both sexes combined) was estimated as $1000 \mathrm{~g}$ (Anderson et al. 2009), and assimilation efficiency (AE) of AFDM was estimated as 0.75 (Richman \& Lovvorn 2003). We assumed the energy density (ED) of prey was $21 \mathrm{~kJ} \mathrm{~g}^{-1}$ AFDM, which is appropriate for mussels and most other invertebrates consumed by surf scoters (Steimle \& Terranova 1985). For each of the 2 yr that we conducted biweekly surveys in Penn Cove, we estimated surf scoter use days (SSUD) by interpolating the number present on each date using the means of consecutive surveys and then summing the daily totals for the period from 1 September through 31 January (i.e. the period of peak surf scoter use of Penn Cove; see 'Results'). We compared the total energy requirements of surf scoters during this period to the availability in late August of mussels and polychaetes, the 2 main foods observed in surf scoter diets in Penn Cove (see 'Results'). We used $4.35 \times 10^{5}$ and $3.4 \times$ $10^{6} \mathrm{~m}^{2}$ as estimates of the area in Penn Cove that supported mussels and polychaetes, respectively.

For the isopod Idotea resecata and caridean shrimp in Padilla Bay, we used ANOVA to contrast body length among the 3 sampling seasons, but statistical tests were not conducted on AFDM per individual because these estimates were based on pooled samples. For all analyses, post hoc tests were conducted on least-squares means using the Tukey honestly signifi- 
cant difference (HSD) method of adjusting for multiple comparisons. We transformed all AFDM values and crustacean body lengths using $\ln$ (variable +1 ). These transformations generally reduced, but did not eliminate, deviations from the assumption of normality (Shapiro-Wilk test); however, general linear models are typically robust to such deviations (Sheskin $2007)$. We report all means $( \pm$ SE) for back-transformed data, and set all significance levels at $\alpha=0.05$.

\section{Seasonal variation in prey biomass}

For all major taxa of infaunal and epifaunal prey, total biomass (AFDM) independent of prey size either displayed little change among sampling seasons, or else seasonal changes were the reverse of those expected based on seasonal patterns of use by scoters (Tables $1 \& 2$, Figs. 4 to 6). In seagrass beds of Padilla Bay during 2005, total biomass increased for

\section{RESULTS}

\section{Surf scoter counts and diets}

Numbers of surf scoters Melanitta perspicillata in Penn Cove peaked at 5000 to 8000 ind. between November and January, and then declined through spring (Fig. 3). In Padilla Bay, numbers of surf scoters peaked at $>8000$ ind. during spring staging in late April to early May and again during wing molt in late August to early September. These results are based on our biweekly surveys and supplemental observations which together indicated that seasonal patterns of change in scoter numbers within each site were similar during all 3 years, except in Penn Cove where the timing of mid-winter declines in surf scoter numbers varied among years and occurred earlier in 2005-2006 than in the 2 preceding years.

In Penn Cove, surf scoters ate mainly mussels in autumn and then, as winter progressed, fed mainly on polychaetes (Fig. 3). In Padilla Bay during both spring and summer, surf scoters ate mainly crustaceans (crabs and the isopod Idotea resecata) and secondarily gastropods and bivalves (Fig. 3). Crab taxa eaten in Padilla Bay during March included Pinnotheridae (17\%), and in August included unidentified crabs (39\%), Metacarcinus magister $(21 \%)$, and Pinnotheridae $(<1 \%)$. Caridean shrimp were not detected in the diet of the surf scoters we collected in Padilla Bay, nor in the fecal remains of 51 surf scoters captured there during late summer of 2009 (Tschaekofske 2010).


Fig. 3. Melanitta perspicillata. Seasonal numbers (vertical bars) and diet estimates (pie charts) of surf scoters from 2003 to 2006 in Penn Cove and Padilla Bay, Washington. $\nabla$ : dates on which counts were conducted but no surf scoters were observed. Diet estimates for surf scoters as mean percent of ash-free dry mass (AFDM) of esophagus contents (Penn Cove 2005, Padilla Bay 2006), or the mean percent AFDM of gizzard contents for periods when all esophagi were empty (Penn Cove 2003, Padilla Bay 2005). n: numbers of birds that contained foods in the respective organs. I.: Idotea 
Table 1. Seasonal changes in infaunal biomass $\left(\mathrm{g} \mathrm{AFDM} \mathrm{m}^{-3}\right.$ ) in Penn Cove and Padilla Bay, Washington. Effects of size class were tested only for bivalves. Results are based on all sediment burial depths (0 to $10 \mathrm{~cm}$ ) and all water depths (all sampling stations) and models that include all parameters (see 'Data analyses and computations'). Seasons include November to January (W: winter), March to May (Sp: spring), and August (Su: summer). HSD: Tukey's honestly significant difference test. See Figs. 4 \& 5 for AFDM estimates. Seasonal changes in the biomass of infaunal prey at sediment burial depths $<5 \mathrm{~cm}$ did not differ from those for all depths except for Bivalvia in Penn Cove for which there was no seasonal trend in sediments $<5 \mathrm{~cm}(\mathrm{p}>$ 0.372). Seasonal changes in the biomass of infaunal prey in shallower water depths nearshore (see 'Materials and methods') did not differ from those for all depths except for Bivalvia and Crustacea in Penn Cove and Crustacea and Ophiuriodea in Padilla Bay for which there was no seasonal trend in shallow water depths (all $p>0.235$ )

\begin{tabular}{|c|c|c|c|c|c|c|}
\hline & $\begin{array}{l}\text { Season, } \\
\mathrm{p}\end{array}$ & $\begin{array}{c}\text { Penn Co } \\
\text { Season } \times \text { Size class } \\
\mathrm{p}\end{array}$ & $\begin{array}{c}\text { ove } \\
\text { Tukey HSD, } \\
\mathrm{p}<0.05\end{array}$ & $\underset{\mathrm{p}}{\text { Season, }}$ & $\begin{array}{c}\text { Padilla Bay } \\
\text { Season } \times \text { Size class, } \\
\mathrm{p}\end{array}$ & $\begin{array}{c}\text { Tukey HSD, } \\
p<0.05\end{array}$ \\
\hline \multicolumn{7}{|l|}{ 2003-2004 } \\
\hline Bivalvia & 0.085 & 0.002 & $\begin{array}{c}31-40 \mathrm{~mm}: \mathrm{Sp}=\mathrm{Su}>\mathrm{W} \\
41-60 \mathrm{~mm}: \mathrm{Sp}>\mathrm{W}\end{array}$ & 0.394 & 0.334 & \\
\hline Crustacea & 0.024 & & $\mathrm{Sp}>\mathrm{W}$ & 0.519 & & \\
\hline Polychaeta & 0.213 & & & $<0.001$ & & $\mathrm{~W}>\mathrm{Sp}=\mathrm{Su}$ \\
\hline Ophiuroidea & 0.547 & & & 0.001 & & $\mathrm{~W}>\mathrm{Su}$ \\
\hline \multicolumn{7}{|l|}{ 2004-2005 } \\
\hline Bivalvia & 0.288 & 0.320 & & 0.796 & 0.498 & \\
\hline Crustacea & 0.496 & & & $<0.001$ & & $\mathrm{Su}>\mathrm{W}=\mathrm{Sp}$ \\
\hline Polychaeta & 0.854 & & & $<0.001$ & & $\mathrm{Sp}>\mathrm{W}>\mathrm{Su}$ \\
\hline Ophiuroidea & 0.058 & & & 0.002 & & $\mathrm{~W}=\mathrm{Sp}>\mathrm{Su}$ \\
\hline
\end{tabular}

Table 2. Seasonal changes in the biomass of mussels (g AFDM m ${ }^{-2}$ ) and other epifauna (g AFDM $\mathrm{m}^{-3}$ ) in Penn Cove and Padilla Bay from 2003 to 2004 and 2004 to 2005 combined. Effects of size class were tested only for mussels in Penn Cove. Results for gastropods and crustaceans are based on all water depths, and all results are based on models that include all parameters (see 'Data analyses and computations'). See Table 1 for season conventions and other abbreviations, and Fig. 6 for AFDM estimates. Seasonal changes in the biomass of epifaunal Gastropoda and Crustacea at shallow water depths nearshore (see 'Materials and methods') did not differ from those for all depths, except for Gastropoda in Penn Cove for which biomass was

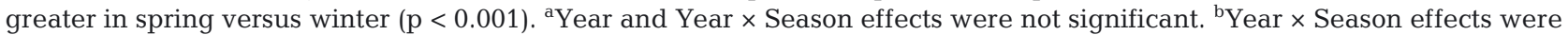
not significant, and Year effects were not significant, except in Penn Cove where AFDM of Gastropoda and Crustacea were each slightly greater in 2004-2005 versus 2003-2004

\begin{tabular}{|c|c|c|c|c|c|}
\hline & \multicolumn{3}{|c|}{ - Penn Cove - } & \multicolumn{2}{|c|}{ — Padilla Bay } \\
\hline & $\begin{array}{c}\text { Season, } \\
\mathrm{p}\end{array}$ & $\begin{array}{c}\text { Season } \times \text { Size class, } \\
\mathrm{p}\end{array}$ & $\begin{array}{c}\text { Tukey HSD, } \\
\mathrm{p}<0.05\end{array}$ & $\begin{array}{c}\text { Season, } \\
\mathrm{p}\end{array}$ & $\begin{array}{c}\text { Tukey HSD, } \\
\mathrm{p}<0.05\end{array}$ \\
\hline Mussels $^{\mathrm{a}}$ & 0.418 & 0.008 & $\begin{aligned} 2-20 \mathrm{~mm}: \mathrm{Su}>\mathrm{W}=\mathrm{Sp} \\
21-30 \mathrm{~mm}: \mathrm{Su}>\mathrm{W}=\mathrm{Sp}\end{aligned}$ & & \\
\hline Gastropoda $^{\mathrm{b}}$ & 0.209 & & & 0.016 & $\mathrm{Su}>\mathrm{W}=\mathrm{Sp}$ \\
\hline Crustacea $^{\mathrm{b}}$ & 0.767 & & & $<0.001$ & $\mathrm{~W}=\mathrm{Sp}>\mathrm{Su}$ \\
\hline
\end{tabular}

infaunal polychaetes in spring and for infaunal crustaceans and epifaunal gastropods in summer (Tables 1 $\& 2$, Figs. $5 \& 6$ ). However, these prey increases in Padilla Bay did not appear to underlie peaks in surf scoter numbers during spring and summer because infaunal polychaetes were rare in surf scoter diets and because dietary fractions of gastropods and infaunal crustaceans did not increase from spring to summer when availability of these prey items had increased (Fig. 3).

\section{Seasonal variation in sediment burial depth and water depth of prey}

During the years we sampled prey in Penn Cove, surf scoters fed at increasingly greater water depths as winter progressed (Anderson \& Lovvorn 2011). This seasonal increase in diving depths corresponded to (1) declines in small mussels (2 to $30 \mathrm{~mm}$, see below) that were restricted to intertidal elevations and (2) shifts in diet from mussels to polychaetes that 


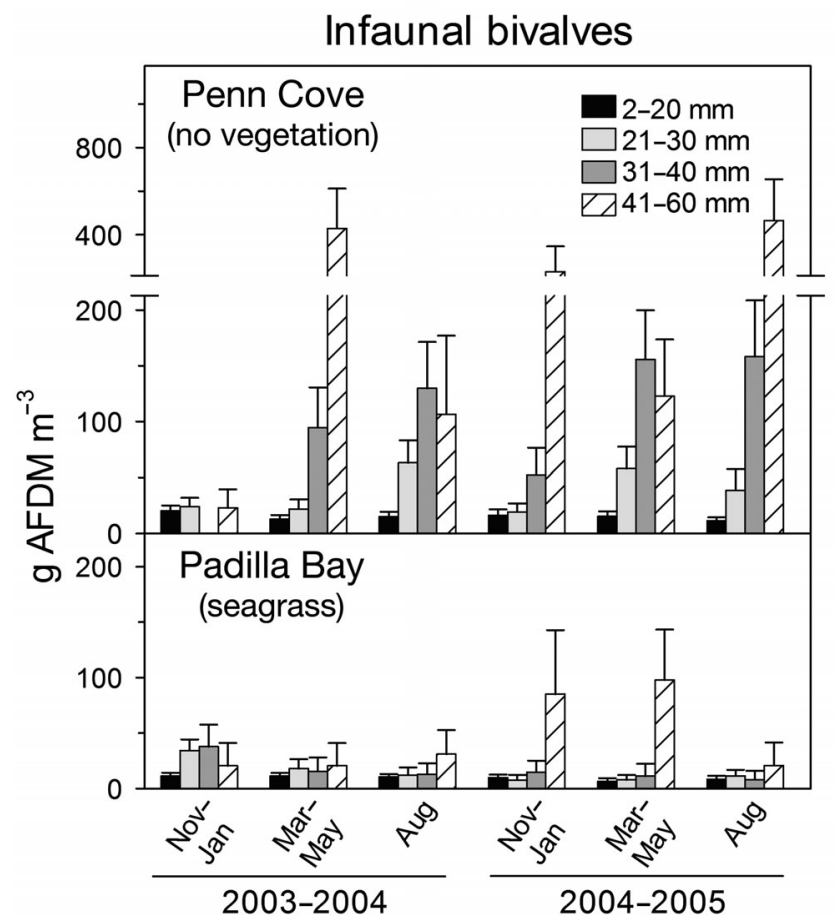

Fig. 4. Seasonal biomass (AFDM, mean + SE) of infaunal bivalves (0 to $10 \mathrm{~cm}$ burial depth) by shell length class in Penn Cove and Padilla Bay ( $\mathrm{n}=20$ to 24 triplicate sampling stations per period at each site). Bivalves consumed by surf scoters Melanitta perspicillata in this study were $<30 \mathrm{~mm}$ in length (Fig. 2), and seasonal trends in biomass of infaunal bivalves within this size range were not consistent with trends in scoter numbers or diet at either site

were mainly subtidal (polychaete AFDM m ${ }^{-3}$ [mean \pm SE] across sampling seasons was $28.8 \pm 3.1 \mathrm{~g}$ and $51.2 \pm 6.8 \mathrm{~g}$ at the intertidal $(\mathrm{n}=8)$ and subtidal $(\mathrm{n}=4)$ stations, respectively; $p<0.001$ ). For other prey types at each site, our analyses did not suggest that seasonal changes in prey distributions relative to sediment burial depth or water depth had led to changes in surf scoter numbers or diets (Tables 1 \& 2, Fig. 3).

\section{Penn Cove prey availability and surf scoter energy needs}

During the peak period of surf scoter numbers in Penn Cove from 1 September to 31 January, their total energy requirements in terms of invertebrate biomass (AFDM) were $32450 \mathrm{~kg}$ in 2003-2004 and $39749 \mathrm{~kg}$ in 2004-2005. Smaller mussels (2 to $30 \mathrm{~mm}$ ) appeared to be a preferred prey item in autumn (Figs. $2 \& 3$ ). However, they were not a profitable option throughout winter because their availability in August $2004(13080 \mathrm{~kg})$ and $2005(13533 \mathrm{~kg})$ was

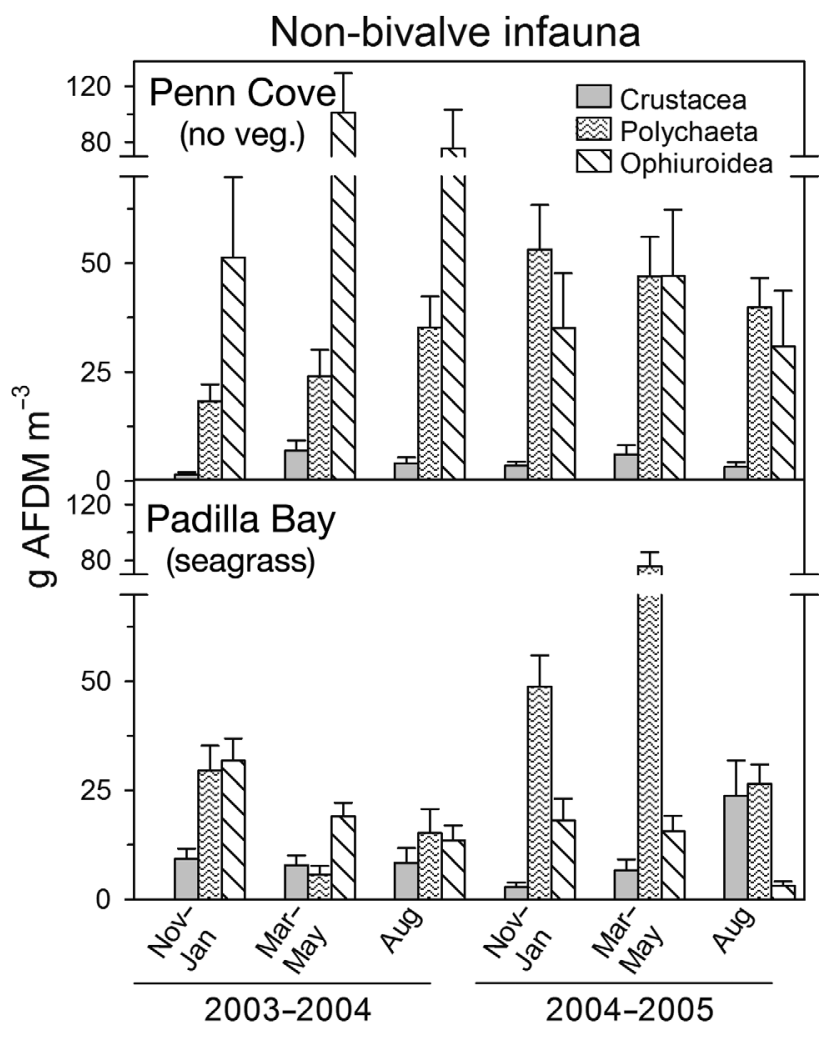

Fig. 5. Seasonal biomass (AFDM, mean + SE) of non-bivalve infauna (0 to $10 \mathrm{~cm}$ burial depth) in Penn Cove and Padilla Bay ( $\mathrm{n}=20$ to 24 triplicate sampling stations per period at each site). Seasonal trends in biomass of non-bivalve infauna were not consistent with trends in surf scoter

Melanitta perspicillata numbers or diet at either site

adequate to support just 33 to $42 \%$ of total energy needs for all scoters present in Penn Cove from September through January. This percent range encompasses all combinations of the 2 annual estimates of scoter needs and mussel biomass and is used to indicate conditions in typical years since scoter counts and prey surveys did not co-occur in both years. In contrast, the additional biomass available in larger mussels (31 to $60 \mathrm{~mm}$ ) and polychaetes was adequate to meet 134 to $223 \%$ and 302 to $418 \%$, respectively, of scoter needs from 1 September to 31 January. Thus, surf scoters departed Penn Cove in mid-winter even though the availability of larger mussels and of polychaetes each surpassed scoter energy needs and showed no indication of declining over winter.

\section{Seasonal size dynamics of prey}

On the unvegetated sediments of Penn Cove, the biomass of larger mussels ( 31 to $60 \mathrm{~mm}$ ) did not vary among seasons, yet the biomass of smaller mussels ( 2 
to $30 \mathrm{~mm}$ ) peaked in summer and was $\sim 75 \%$ lower during winter and spring (Table 2, Fig. 6). Surf scoter numbers peaked soon after their arrival in Penn Cove in early autumn when smaller mussels reflected late summer peaks of abundance (winter mussel sampling did not begin until late November). Scoter numbers subsequently declined as small mussels fell to much lower numbers than in late summer (cf. Figs. 3 \& 6). Conversely, availability of all infaunal bivalves by size class did not explain shifts in surf scoter numbers at either site (Table 1, Fig. 4).
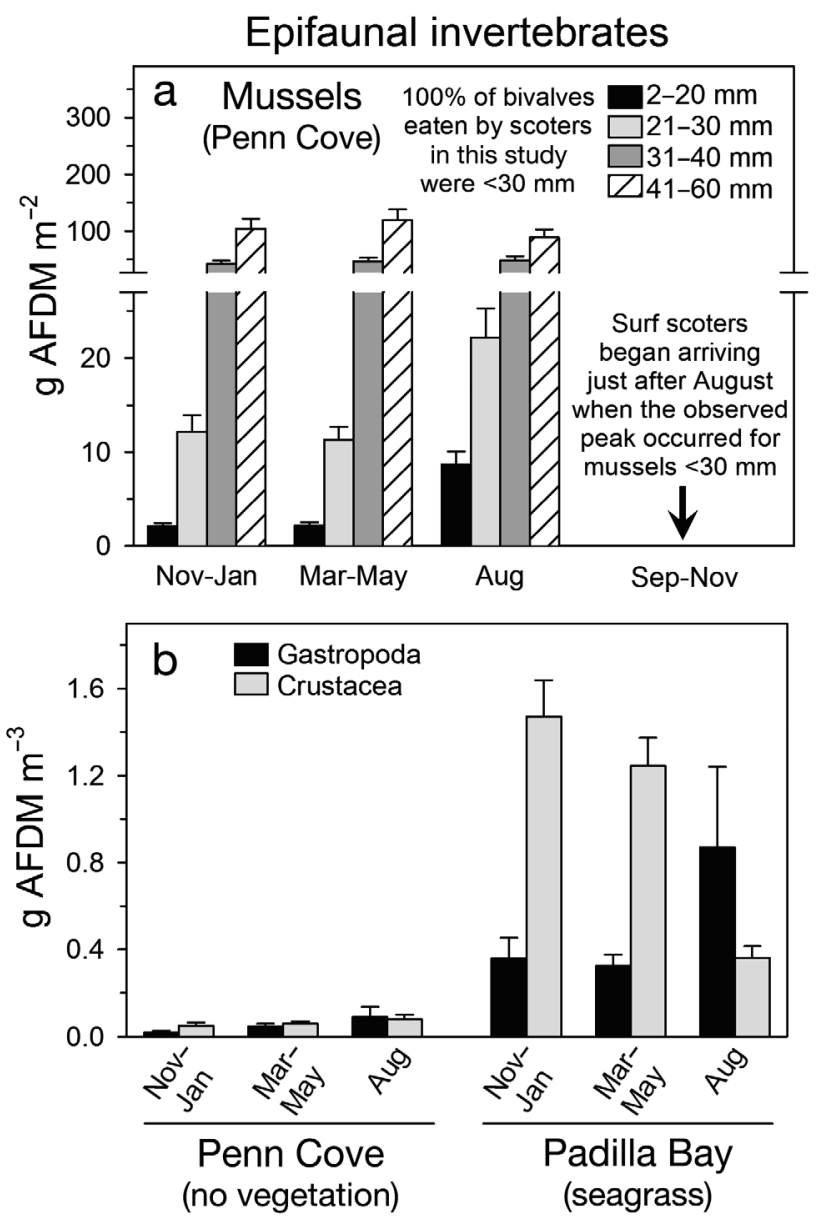

Fig. 6. Seasonal biomass (AFDM, mean + SE) of epifaunal invertebrates including (a) mussels by size class in Penn Cove ( $\mathrm{n}=80$ and 160 sampling stations per period for 2003 to 2004 and 2004 to 2005, respectively) and (b) non-quantitative (epibenthic sled) estimates for gastropods and crustaceans in Penn Cove and Padilla Bay ( $\mathrm{n}=18$ to 27 triplicate sampling stations per period at each site). Data from 2003 to 2004 and 2004 to 2005 were combined since results varied little between years (Table 2). In Penn Cove, peaks in surf scoter Melanitta perspicillata numbers co-occurred with peaks in the biomass of mussels $<30 \mathrm{~mm}$; however, seasonal trends in total biomass of other epifaunal prey were not consistent with trends in surf scoter numbers or diet at either site
In the seagrass beds of Padilla Bay, peaks in surf scoter numbers co-occurred with increased sizes of crustacean prey. In Padilla Bay, 21 \% of surf scoter diet in August consisted of the crab Metacarcinus magister, for which body size increases from winter to summer according to past studies (numbers of crabs in our prey samples were not adequate to assess their size structure, see 'Discussion'; Fig. 7a). The isopod Idotea

Padilla Bay epifauna (seagrass)

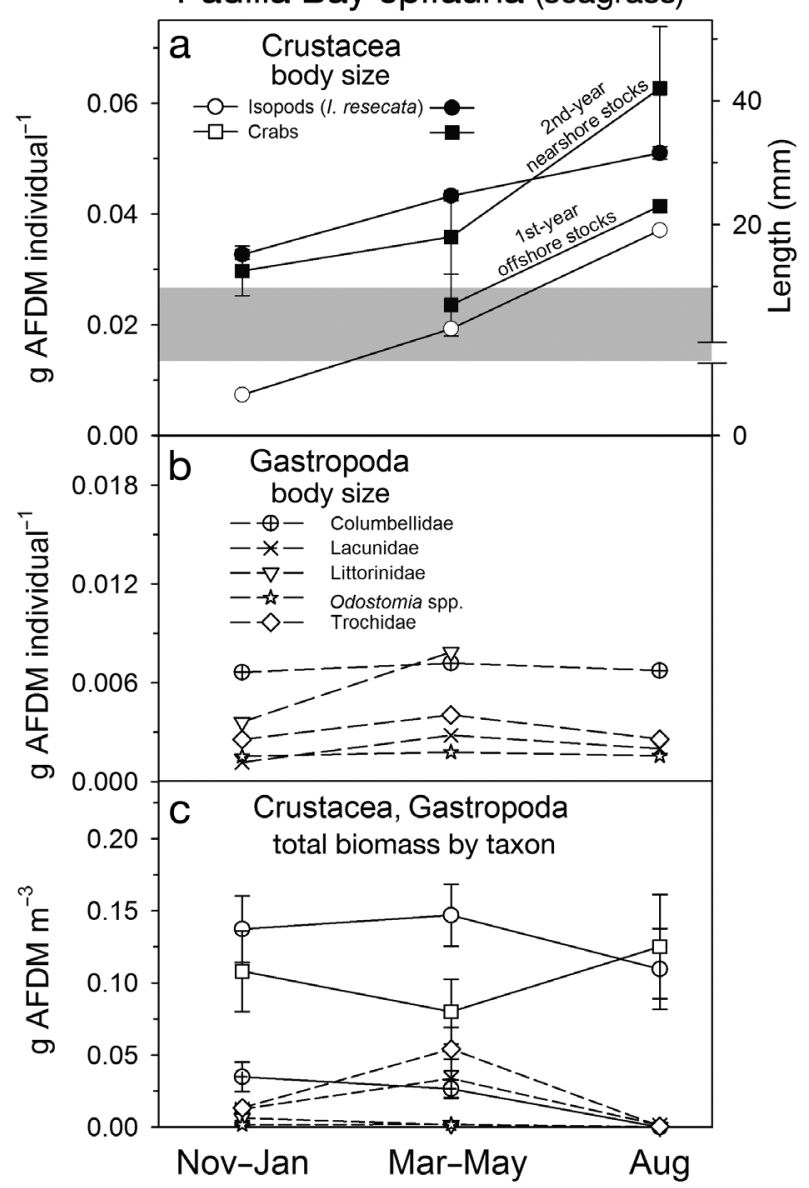

Fig. 7. Seasonal changes in mean body size of surf scoter Melanitta perspicillata prey in Padilla Bay for (a) 2 crustacean taxa (I.: Idotea) that comprised 50 to $73 \%$ of their diet and (b) 5 gastropod taxa that comprised 12 to $27 \%$ of their diet (open symbols: AFDM; closed symbols: length). Means for AFDM lack error bars because individuals were pooled for analysis. (a) Carapace widths of crabs are for 2 cohorts of Metacarcinus magister (1st-year offshore, 2nd-year nearshore) assessed by McMillan et al. (1995) in Padilla Bay and 4 other sites in Puget Sound; older cohorts were likely too large to be eaten by surf scoters. For comparison, the shaded region in (a) is the seasonal range of AFDM in Penn Cove for a mussel $14 \mathrm{~mm}$ long (the mean length of bivalves eaten by surf scoters in past studies; Fig. 2). (b) Numbers of Littorinidae in prey samples were inadequate to assess their size in August. (c) Seasonal trends in total biomass for each taxon (symbols as in [a] and [b]) in Padilla Bay (crab biomass includes all crab taxa in our prey surveys) 
resecata comprised 12 to $33 \%$ of the scoter diet in Padilla Bay during spring and summer (Fig. 3), the seasonal periods when these isopods displayed increased body size (body length: $\mathrm{p}<0.001$, and $\mathrm{p}<0.05$ in Tukey HSD tests for all seasonal contrasts; Fig. 7a). Although not observed in scoter diet, caridean shrimp increased in length by $\sim 100 \%$ and in biomass by $250 \%$ from winter to spring and then changed little from spring to summer (in winter, shrimp size (mean \pm SE) was $13 \pm 1 \mathrm{~mm}$ and $0.006 \mathrm{~g}$ AFDM).

In Padilla Bay seagrass beds, surf scoters also ate appreciable amounts of gastropods (Fig. 3), so we assessed the size dynamics of gastropod taxa that appeared in their diets. While numbers of surf scoters increased there in both spring and summer, increased body size of most gastropods they ate occurred mainly in spring and were slight compared to size increases in crustaceans (Fig. 7b). Body size of gastropods was assessed only in terms of AFDM per individual, because their shell lengths remained within the range of shelled prey that surf scoters commonly ingest (5 to $15 \mathrm{~mm}$; Fig. 2). Although not observed in surf scoter diets in Padilla Bay, the gastropod Haminoea vesicula showed pronounced increases in body size that co-occurred with peaks in surf scoter numbers and also accounted for $100 \%$ of the increase in the biomass of all gastropods during summer in Padilla Bay. In contrast to the seasonal size dynamics of crabs and the isopod Idotea resecata in Padilla Bay (Fig. 7a), total biomass of each epifaunal taxa that appeared in scoter diets did not vary by season in accordance with surf scoter numbers at that site (i.e. for each taxa, Tukey HSD tests did not indicate that total biomass was greater in spring and summer compared to winter; Fig. 7c).

\section{DISCUSSION}

More so than the changes in alternative prey attributes we assessed (total biomass, burial depth in sediments, water depth), the seasonal size dynamics of epifaunal prey appeared to underlie shifts in surf scoter Melanitta perspicillata numbers between 2 heavily used feeding sites (Table 3). Many thousands of surf scoters fed during early winter in Penn Cove, where profitable foraging during that period appeared to be limited mainly to small mussels (2 to $30 \mathrm{~mm}$ ). Early winter declines in these small mussels, which were adequate in August to meet less than half the total energy needs for all scoters in Penn Cove from September to January, led to a shift in diet to mainly subtidal polychaetes and corresponding departures of surf scoters for other feeding sites. These results suggest that polychaetes and larger mussels (31 to $60 \mathrm{~mm}$ ) were not profitable alternatives, despite the fact that availability of each of these prey types far surpassed scoter energy needs.

During pre-migratory fattening in spring and during feather molt in summer, >8000 surf scoters aggregated in the seagrass-dominated Padilla Bay where their diets included mainly epifaunal crustaceans (50 to $73 \%$ ) and gastropods (12 to $27 \%$ ). In Padilla Bay, the body size of crustacean prey had increased substantially since winter (Fig. 7a), and scoters relied on taxa of crustaceans whose mobility was relatively low and did not increase with body size. Seasonal changes in prey biomass independent of prey size, and in prey distributions relative to burial depth in sediments and water depth, were less pronounced or inconsistent with changes in surf

Table 3. Melanitta perspicillata. Evidence of possible factors causing shifts in surf scoter numbers at an unvegetated mussel site (Penn Cove) and a seagrass site (Padilla Bay)

Possible reasons for shifts in surf scoter numbers

Inference from present study

Penn Cove (no vegetation, mussel site)

Surf scoters declined in early winter due to:

(1) Decreased total biomass of prey

(2) Increased sediment depth of infaunal prey

(3) Increased water depth of prey

(4) Change in prey size structure

\section{Padilla Bay (seagrass site)}

Surf scoters increased in spring and summer due to:

(1) Increased total biomass of prey

(2) Decreased sediment depth of infaunal prey

(3) Decreased water depth of prey

(4) Change in prey size structure
No for prey eaten by surf scoters (Tables 1 \& 2, Figs. 3 to 6)

No (Table 1)

No (Tables $1 \& 2$ )

Yes - surf scoters relied heavily on small mussels $(2-30 \mathrm{~mm})$ which then declined in number over winter (Table 2, Figs. 2, 3,6)

No for prey eaten by surf scoters (Tables 1 \& 2, Figs. 3 to 7 )

No (Table 1)

No (Tables 1 \& 2)

Yes - surf scoters relied heavily on prey that had increased in size since early winter (Figs. 3 \& 7) 
scoter numbers and diet at each site (Table 3). Complementary data on surf scoter foraging effort and body condition (plasma metabolites, body composition) support the conclusion that relative foraging profitability was higher during early winter in Penn Cove, but then declined there and shifted in favor of Padilla Bay during spring (Anderson \& Lovvorn 2011).

In Penn Cove, where shelled prey (mussels) were the main food for surf scoters during early winter, our results are consistent with past reports that profitability declines with increasing bivalve sizes. Past studies suggested 2 possible reasons why diving birds commonly select smaller sizes than those that maximize energy intake. (1) Selecting smaller bivalves reduces the risk of obtaining prey items too large to ingest (Draulans 1984). (2) Instead of maximizing energy intake, birds may select sizes of bivalves that minimize shell intake (Bustnes \& Erikstad 1990). The tendency to select smaller bivalves than those that maximize energy intake may be common in other taxa of bivalve predators, perhaps also to minimize handling time and thus exposure to kleptoparasitism (Hughes \& Dunkin 1984). Relative to polychaetes, the greater profitability of small mussels likely resulted from their more clustered distribution above the sediment surface and at shallower water depths.

In contrast to shelled prey, the profitability of seagrass crustaceans to surf scoters appeared to increase with prey size as long as prey mobility was relatively low. From winter to summer, lengths of Metacarcinus magister crabs, Idotea resecata isopods, and caridean shrimp approximately doubled, with the biomass per individual of $I$. resecata increasing by $\sim 300 \%$ (Fig. 7a). As we had predicted, I. resecata comprised a significant fraction of surf scoter diet in Padilla Bay (12 to 33\%), whereas caridean shrimp did not. I. resecata shows no change in swimming velocity with size $\left(0.2 \mathrm{~m} \mathrm{~s}^{-1}\right.$; Alexander \& Chen 1990), while velocity is greater and increases markedly with size in caridean shrimp ( 0.5 versus $>1.0 \mathrm{~m} \mathrm{~s}^{-1}$ at 10 and $30 \mathrm{~mm}$ body lengths, respectively; Arnott et al. 1998). This effect of prey size and mobility may also explain the even greater consumption of crabs than of I. resecata in Padilla Bay. Compared to $I$. resecata, the crab M. magister displayed similar seasonal size dynamics (McMillan et al. 1995), while crab mobility is much lower (Freire \& González-Gurriarán 1998). Accordingly, the dietary fraction of crabs for surf scoters in Padilla Bay was 2 to 5 times greater than for I. resecata. Crab taxa in addition to $M$. magister likely display similar sea- sonal patterns in size structure, because water temperature limits the main period of growth to about March through September (McMillan et al. 1995). Further, most crustacean taxa may similarly attain greatest body sizes during spring and summer (Sparrevik \& Leonardsson 1999, Jeong et al. 2009). As was likely the case for the surf scoters in our study, increased mobility of their crustacean prey meant reduced capture success. However, if prey density surpasses some threshold, profitability can increase with prey mobility as a result of elevated encounter rates having a greater effect than reduced capture success (Sih \& Christensen 2001).

\section{Complementarity of mussel and seagrass habitats}

A number of studies have compared faunal abundance and diversity between unvegetated and seagrass habitats (Connolly 1997, Rozas \& Minello 1998, Nagelkerken \& van der Velde 2004). Although some fish species are more common over unvegetated sediments, their densities are often higher if seagrass beds are nearby. This effect is often attributed to the nursery functions of seagrass for providing fish recruits to adjacent areas, or to proximity of vegetative cover for fishes that feed over unvegetated sediments on a diel schedule (Gray et al. 1998, Nagelkerken et al. 2001). Our study has shown yet another complementary habitat relationship that depends on the seasonal size dynamics of prey for avian predators. Our energetics calculations for scoters, and seasonal changes in their distributions, diets, and availability of prey, demonstrate that both unvegetated and seagrass habitats are needed to sustain the birds throughout their time in Puget Sound. Without information on the seasonality of prey size structure, the basis of this dependency for this mobile top predator would not have been apparent. These results also suggest that widespread declines in seagrass may have contributed to declines in surf scoters and other species of marine birds that rely on seagrass habitat for seasonal feeding (Laubhan \& Metzner 1999, Orth et al. 2006).

Acknowledgements. We thank E. Mischke for sorting invertebrate samples. Field assistance was provided by M. Axelson, J. Barone, R. Corcoran, T. Cyra, D. Drewry, C. Engelhardt, J. Evenson, T. Nixon, D. Nysewander, B. Otto, J. Otto, J. Otto III, and B. Welton. Surf scoters were collected under the authority of permits from the US Fish and Wildlife Service (MB111993-0) and the Washington Department of Fish and Wildlife (05-608). This study was funded by the SeaDoc Society of the Wildlife Health Center at the UC Davis School of 
Veterinary Medicine (K004431-19), the Sea Duck Joint Venture (701816M183), the US Fish and Wildlife Service Western Washington Fish and Wildlife Office (13410-5-J008), the National Science Foundation Office of Polar Programs (OPP9813979 and ARC-0454454 to J.R.L.), and fellowships to E.M.A. from the National Oceanic and Atmospheric Administration National Estuarine Research Reserve System (Graduate Research Fellowship NA03NOS4200048), the Wyoming National Aeronautics and Space Administration Space Grant Consortium, Wyoming NASA EPSCoR (NCC5-578), the National Science Foundation GK12 Program (DGE-0538642), and the University of Wyoming Robert and Carol Berry Biodiversity Conservation Center.

\section{LITERATURE CITED}

Alexander DE, Chen T (1990) Comparison of swimming speed and hydrodynamic drag in two species of Idotea (Isopoda). J Crustac Biol 10:406-412

Anderson EM, Lovvorn JR (2011) Contrasts in energy status and marine foraging strategies of white-winged scoters (Melanitta fusca) and surf scoters (M. perspicillata). Auk 128:248-257

> Anderson EM, Lovvorn JR, Esler D, Boyd WS, Stick KC (2009) Using predator distributions, diet, and condition to evaluate seasonal foraging sites: sea ducks and herring spawn. Mar Ecol Prog Ser 386:287-302

- Anderson EM, Lovvorn JR, Wilson MT (2008) Reevaluating marine diets of surf and white-winged scoters: interspecific differences and the importance of soft-bodied prey. Condor 110:285-295

> Arnott SA, Neil DM, Ansell AD (1998) Tail-flip mechanism and size-dependent kinematics of escape swimming in the brown shrimp Crangon crangon. J Exp Biol 201: 1771-1784

> Asmus H (1987) Secondary production of an intertidal mussel bed community related to its storage and turnover compartments. Mar Ecol Prog Ser 39:251-266

Beukema JJ, Dekker R (2007) Variability in annual recruitment success as a determinant of long-term and largescale variation in annual production of intertidal Wadden Sea mussels (Mytilus edulis). Helgol Mar Res 61:71-86

Bulthuis DA (1995) Distribution of seagrasses in a north Puget Sound estuary: Padilla Bay, Washington, USA. Aquat Bot 50:99-105

Bustnes JO, Erikstad KE (1990) Size selection of common mussels, Mytilus edulis, by common eiders, Somateria mollissima: energy maximization or shell weight minimization? Can J Zool 68:2280-2283

> Ceccherelli VU, Rossi R (1984) Settlement, growth and production of the mussel Mytilus galloprovincialis. Mar Ecol Prog Ser 16:173-184

Christensen B (1996) Predator foraging capabilities and prey antipredator behaviours: pre- versus postcapture constraints on size-dependent predator-prey interactions. Oikos 76:368-380

> Connolly RM (1997) Differences in composition of small, motile invertebrate assemblages from seagrass and unvegetated habitats in a southern Australian estuary. Hydrobiologia 346:137-148

Costa GC (2009) Predator size, prey size, and dietary niche breadth relationships in marine predators. Ecology 90: 2014-2019

Craeymeersch JA, Herman PMJ, Meire PM (1986) Second- ary production of an intertidal mussel (Mytilus edulis L.) population in the eastern Scheldt (S.W. Netherlands). Hydrobiologia 133:107-115

> Crowder LB, Cooper WE (1982) Habitat structural complexity and the interaction between bluegills and their prey. Ecology 63:1802-1813

Dare PJ (1976) Settlement, growth and production of the mussel, Mytilus edulis L., in Morecambe Bay, England. Fish Invest II 28:1-25

$>$ Draulans D (1984) Sub-optimal mussel selection by tufted ducks Aythya fuligula: test of a hypothesis. Anim Behav 32:1192-1196

> Durell SEA le V dit, Stillman RA, Triplet P, Aulert C and others (2005) Modeling the efficacy of proposed mitigation areas for shorebirds: a case study on the Seine estuary, France. Biol Conserv 123:67-77

> Edgar GJ (1990a) The influence of plant structure on the species richness, biomass and secondary production of macrofaunal assemblages associated with Western Australian seagrass beds. J Exp Mar Biol Ecol 137:215-240

Edgar GJ (1990b) Population regulation, population dynamics and competition amongst mobile epifauna associated with seagrass. J Exp Mar Biol Ecol 144:205-234

Edgar GJ, Shaw C (1995) The production and trophic ecology of shallow-water fish assemblages in southern Australia. III. General relationships between sediments, seagrasses, invertebrates and fishes. J Exp Mar Biol Ecol 194:107-131

Edgar GJ, Watson G, Hammond LS, Shaw C (1994) Comparisons of species richness, size-structure and production of benthos in vegetated and unvegetated habitats in Western Port, Victoria. J Exp Mar Biol Ecol 176:201-226

Faldborg K, Jensen KT, Maagaard L (1994) Dynamics, growth, secondary production and elimination by waterfowl of an intertidal population of Mytilus edulis L. Ophelia Suppl 6:187-200

Fredette TJ, Diaz RJ, van Montfrans J, Orth RJ (1990) Secondary production within a seagrass bed (Zostera marina and Ruppia maritima) in Lower Chesapeake Bay. Estuaries 13:431-440

Freire J, González-Gurriarán E (1998) New approaches to the behavioural ecology of decapod crustaceans using telemetry and electronic tags. Hydrobiologia 371/372: $123-132$

Goss-Custard JD, Stillman RA, West AD, Caldow RWG, Mcgrorty S (2002) Carrying capacity in overwintering migratory birds. Biol Conserv 105:27-41

Goudie RI, Ankney CD (1986) Body size, activity budgets, and diets of sea ducks wintering in Newfoundland. Ecology 67:1475-1482

Gray CA, Chick RC, McElligott DJ (1998) Diel changes in assemblages of fishes associated with shallow seagrass and bare sand. Estuar Coast Shelf Sci 46:849-859

Hamilton DJ (2000) Direct and indirect effects of predation by common eiders and abiotic disturbance in an intertidal community. Ecol Monogr 70:21-43

Hamilton DJ, Nudds TD, Neate J (1999) Size-selective predation of blue mussels (Mytilus edulis) by common eiders (Somateria mollissima) under controlled field conditions. Auk 116:403-416

Heck KL Jr, Orth RJ (2006) Predation in seagrass beds. Larkum AWD, Orth RJ, Duarte CM (eds) Seagrass biology. Springer, Heidelberg

Heck KL Jr, Able KW, Roman CT, Fahay MP (1995) Composition, abundance, biomass, and production of macro- 
fauna in a New England estuary: comparisons among eelgrass meadows and other nursery habitats. Estuaries 18:379-389

Hughes RN, Dunkin S de B (1984) Behavioural components of prey selection by dogwhelks, Nucella lapillus L., feeding on mussels, Mytilus edulis L., in the laboratory. J Exp Mar Biol Ecol 77:45-68

$>$ Jeong SJ, Yu OH, Suh HL (2009) Reproductive patterns and secondary production of Gammaropsis japonicus (Crustacea, Amphipoda) on the seagrass Zostera marina of Korea. Hydrobiologia 623:63-76

Kirk M, Esler D, Boyd WS (2007) Morphology and density of mussels on natural and aquaculture structure habitats: implications for sea duck predators. Mar Ecol Prog Ser 346:179-187

Kozloff EN (1996) Marine invertebrates of the Pacific Northwest. University of Washington Press, Seattle, WA

> Laubhan MK, Metzner KA (1999) Distribution and diurnal behavior of Steller's eiders wintering on the Alaska Peninsula. Condor 101:694-698

> Lovvorn JR (1994) Biomechanics and foraging profitability: an approach to assessing trophic needs and impacts of diving ducks. Hydrobiologia 279/280:223-233

Lovvorn JR, Gillingham MP (1996) Food dispersion and foraging energetics: a mechanistic synthesis for field studies of avian benthivores. Ecology 77:435-451

Lundvall D, Svanbäck R, Persson L, Byström P (1999) Sizedependent predation in piscivores: interactions between predator foraging and prey avoidance abilities. Can J Zool 56:1285-1292

McMillan RO, Armstrong DA, Dinnel PA (1995) Comparison of intertidal habitat use and growth rates of two northern Puget Sound cohorts of 0+ age Dungeness crab, Cancer magister. Estuaries 18:390-398

Milne H, Dunnet GM (1972) Standing crop, productivity and trophic relations of the fauna of the Ythan estuary. In: Barnes RSK, Green J (eds) The estuarine environment. Applied Science Publishers, London, p 86-106

Nagelkerken I, van der Velde G (2004) A comparison of fish communities of subtidal seagrass beds and sandy seabeds in 13 marine embayments of a Caribbean island, based on species, families, size distribution and functional groups. J Sea Res 52:127-147

Nagelkerken I, Kleijnen S, Klop T, van den Brand RACJ, Cocheret de la Morinière $E$, van der Velde G (2001) Dependence of Caribbean reef fishes on mangroves and seagrass beds as nursery habitats: a comparison of fish faunas between bays with and without mangroves/ seagrass beds. Mar Ecol Prog Ser 214:225-235

- Nagy KA (1987) Field metabolic rate and food requirement scaling in mammals and birds. Ecol Monogr 57:111-128

- Nakaoka M, Toyohara T, Matsumasa M (2001) Seasonal and between-substrate variation in mobile epifaunal community in a multispecific seagrass bed of Otsuchi Bay, Japan. PSZN I: Mar Ecol 22:379-395

Nehls G, Ketzenberg C (2002) Do common eiders Somateria mollissima exhaust their food resources? A study on natural mussel Mytilus edulis beds in the Wadden Sea. Dan Rev Game Biol 16:47-61

Nehls G, Hertzler I, Scheiffarth G (1997) Stable mussel Mytilus edulis beds in the Wadden Sea: They're just for the birds. Helgol Mar Res 51:361-372

Nilsson L (1972) Habitat selection, food choice, and feeding habits of diving ducks in coastal waters of South Sweden during the non-breeding season. Ornis Scand 3:55-78

Nilsson L (1980) Wintering diving duck populations and available food resources in the Baltic. Wildfowl 31:131-143

Nixon SW, Oviatt CA, Rogers C, Taylor K (1971) Mass and metabolism of a mussel bed. Oecologia 8:21-30

Nolet BA, Gyimesi A, Klaassen RHG (2006) Prediction of bird-day carrying capacity on a staging site: a test of depletion models. J Anim Ecol 75:1285-1292

> Orth RJ, Carruthers TJB, Dennison WC, Duarte CM and others (2006) A global crisis for seagrass ecosystems. Bioscience 56:987-996

Ray G (1997) Benthic assemblages of the Padilla Bay National Estuarine Research Reserve, Mount Vernon, Washington. Tech Rep No. 21, Padilla Bay National Estuarine Research Reserve, Mount Vernon, Washington, DC

> Richman SE, Lovvorn JR (2003) Effects of clam species dominance on nutrient and energy acquisition by spectacled eiders in the Bering Sea. Mar Ecol Prog Ser 261:283-297

$>$ Richman SE, Lovvorn JR (2004) Relative foraging value to lesser scaup ducks of native and exotic clams from San Francisco Bay. Ecol Appl 14:1217-1231

$>$ Richman SE, Lovvorn JR (2009) Predator size, prey size, and threshold food densities of diving ducks: Does a common prey base support fewer large animals? J Anim Ecol 78: 1033-1042

Rozas LP, Minello TJ (1998) Nekton use of salt marsh, seagrass, and nonvegetated habitats in a south Texas (USA) estuary. Bull Mar Sci 63:481-501

Sheskin DJ (2007) Handbook of parametric and nonparametric statistical procedures, 4th edn. Chapman \& Hall/CRC, Boca Raton, FL

> Sih A, Christensen B (2001) Optimal diet theory: When does it work, and when and why does it fail? Anim Behav 61: 379-390

Sparrevik E, Leonardsson K (1999) Direct and indirect effects of predation by Saduria entomon (Isopoda) on the sizestructure of Monoporeia affinis (Amphipoda). Oecologia 120:77-86

Steimle FW Jr, Terranova RJ (1985) Energy equivalents of marine organisms from the continental shelf of the temperate northwest Atlantic. J Northwest Atl Fish Sci 6: $117-124$

Stott RS, Olson DP (1973) Food-habitat relationship of sea ducks on the New Hampshire coastline. Ecology 54: 996-1007

Sukhotin AA, Krasnov YV, Galaktionov KV (2008) Subtidal populations of the blue mussel Mytilus edulis as key determinants of waterfowl flocks in the southeastern Barents Sea. Polar Biol 31:1357-1363

Tschaekofske HJ (2010) Prey selection and its relationship to habitat and foraging strategy of molting white-winged (Melanitta fusca) and surf scoters ( $M$. perspicillata) in Puget Sound, WA, and the Strait of Georgia, BC. MS thesis, Evergreen State College, Olympia, WA

> van Gils JA, Piersma T, Dekinga A, Dietz MW (2003) Costbenefit analysis of mollusc-eating in a shorebird. II. Optimizing gizzard size in the face of seasonal demands. J Exp Biol 206:3369-3380

Zwarts L, Wanink JH (1993) How the food supply harvestable by waders in the Wadden Sea depends on the variation in energy density, body weight, biomass, burying depth and behaviour of tidal-flat invertebrates. Neth J Sea Res 31:441-476

Submitted: February 20, 2012; Accepted: July 16, 2012

Proofs received from author(s): October 14, 2012 